\title{
Comparison of biological value and technological properties of oil seed proteins
}

\section{Tamara Nosenko}

National University of food Technologies, Kyiv, Ukraine

Keywords:

Sunflower

Rape

Soy

Protein

Article history:

Received 23.03.2017

Received in revised form

26.05.2017

Accepted 29.06.2017

Corresponding author:

Tamara Nosenko

E-mail:

tamara_nosenko@ukr.net

DOI: $10.24263 / 2304-$

974X-2017-6-2-5

\section{Abstract}

Introduction. The objective of this work was comparative analysis of protein properties of main oil seeds, cultivated in Ukraine, notably rape, sunflower and soy..

Materials and methods. Tetrachimena piriformis (WH-14 strain) cultures were used for the determination of relative nutritive value and toxicity of the protein products. The emulsifying capacity of seed proteins were determined as maximum volumes of emulsified oil relatively to $1 \mathrm{~g}$ of proteins and foaming capacity as volume of foam, obtained at standard conditions relative to volume of protein suspension.

Results and discussion. According to our data biological value of soy proteins were limited by sulfur containing amino acid methionin and cystin $(2,1 \%$ from common amino acid content). There total content was only about $60 \%$ of $\mathrm{FAO} / \mathrm{WHO}$ scale. Biological value of sunflower proteins was limited by three amino acids sulfur containing amino acids $(1,6 \%$ of methionine and cysteine) and lysine (3,0\% from common amino acid content). The contents of majority of indispensable amino acids in rape proteins are $8-57 \%$ higher than $\mathrm{FAO} / \mathrm{WHO}$ scale. The exception are valin and isoleycin with $80-85 \%$ content. Score of sulfur containing amino acid was $157,1 \%$ from $\mathrm{FAO} / \mathrm{WHO}$ scale. Isolated rape proteins had highest technological properties, their solubilities were 16,4 to $38,6 \%$ at different $\mathrm{pH}$, water holding capacity $211 \%$, oil binding capacity - $130 \%$, emulsifying capacity $-140 \mathrm{ml} / \mathrm{g}$, and foaming capacity $-122 \%$.

Conclusions. Investigated protein isolates of oil seeds (soy, sunflower and rape) had no toxicity. Rape proteins isolate had the highest relative biological value and technological properties. 


\section{Introduction}

Oil seeds are cultivated as raw material for vegetable oils production, but their chemical compositions are unique as to content of lipids, proteins and numerous biological active substances. Protein content of oilseeds is on the level or even exceeds their content in cereals. Special place belongs to soy beans as they contain about twice time higher proteins than lipids. Therefore soy beans are cultivated first of all for feed and food proteins production.

Thus the main products of soy bean processing are soy meal and soy oil. Protein content of soy meal varies from 40 to $45 \%$, about $80 \%$ of which are storage proteins [1]. The main soy storage proteins are glycinin and $\beta$-conglycinin, which belong to the legumin (11S globulins) and vicilin (7S globulins) families of proteins, respectively. These two globulins have different polypeptide composition and technological properties [2-4] and they were precipitated at different $\mathrm{pH}$, notably $11 \mathrm{~S}$ globulins - at $\mathrm{pH} 5,8$ and $7 \mathrm{~S}-$ at $\mathrm{pH}$ $4,5[5]$.

Soy meal is using as a source of different protein products. Removal of seed coats and preserving of high PDI (protein dispersion index) are necessary for edible soy meal production. The high PDI of soy meal generates suitable technological properties of proteins. Soy meal with a high PDI is a raw material for soy protein isolates and with a lower PDI - for protein concentrates. When PDI of soy meal is very low such meal can be used for soy meat production, biscuits etc. Thus the technological properties of proteins are very important for vegetable proteins production particularly of edible range.

Traditional technology of edible soy meal, protein concentrates, isolates, extruded and fermented soy products are described in detail in [6]. But Nazareth et al. [7] have shown that soy protein isolates obtained from gas-supported screw-pressed soybean meal had more than $90 \%$ protein content and had exhibited the high water solubility, water-, oil holding and emulsifying capacities and viscosity of suspensions.

Technological properties of isolated seed proteins first of all depend from degree of their denaturation, which in turn is determined by technology of their obtaining and seeds processing. Conformational changes of soy proteins were observed as at $105^{\circ} \mathrm{C}$ and at 23 ${ }^{\circ} \mathrm{C}$ [8]. It was shown [9] that denaturation degree of soy proteins depends on hydrophobicity of organic solvents and water content, hydrophobic solvents have a low denaturing capacity even at high temperatures, the degree of denaturation of proteins increased with the addition of water. Lower alcohols have the highest denaturing ability among the studied solvents. At the same time Lhocine et al. [10] have shown that technological properties of protein isolates, obtained after defatting of soy flour by ethanol or water, were comparable with protein isolates from soy meal extracted by hexane.

Structure, chemical composition and properties of other oil seeds were studied too. Proteins account for about $20 \%$ of sunflower seeds dry weight. The main storage protein of sunflower seeds heliantin as well as soy globulin consist of two fraction - hexamer 11S globulins and threemer $7 \mathrm{~S}$ globulins with a denaturation temperature 65 and $90{ }^{\circ} \mathrm{C}$, respectively [11]. But heliantin has low water solubility and thermo-induced jellification capacity, which complicates using of such proteins in food systems. Nevertheless heliantin has higher thermal stability compare with globulins of other seeds [12]. Detailed analysis of physicochemical, structural and functional properties of sunflower storage proteins was made by Gonzalez-Perez and Vereijken [13]. Thus it was demonstrated increase of solubility of nondenaturated heliantin even at isoelectric point under high ionic strength of solution $(2 \mathrm{M} \mathrm{NaCl})$. At the same time decrease of solubility in a $\mathrm{pH}$ range from 2 to 8,5 
under increase of ionic strength of solution to $0,25 \mathrm{M} \mathrm{NaCl}$ was detected for sunflower protein isolates, obtained from industrial sunflower meal [14].

The main storage protein of Cruciferous seeds is $11 \mathrm{~S}$ globulin - cruciferin account for about $60 \%$ of seed protein content and content of albumin is about $20 \%[15,16]$. Using of rape seeds as source of food and feed proteins is associated with glucosinolates content. The different methods were proposed to avoid content of these substances in rapeseed meal. To decrease glucosinolates content in rapeseed and canola meal Diosady et al. had used two stage extractions of oils from seeds using polar and nonpolar solvent [17-19]. In spite of this method did not promote complete oil recovery from seeds, protein isolates and concentrates obtained from such meal did not contain glucosinolates [20-24]. In addition steam explosion was used for detoxification of rapeseed meals [25] and it was shown that enzyme treatment could be used to decrease of glucosinolates content in meal [26] .

The biological value of oil seed proteins measured as indispensable amino acid content depends first of all from plant species, variety and climate conditions of their growing. Therefore the data about these values varied in different source. The objective of our work was comparative study of biological value and technological properties of proteins of three main oil seed crop notably soy, sunflower and rape.

\section{Materials and methods}

\section{Materials}

Soybeans variety NK25D3 and sunflower seeds variety KP11B were received from Institute of oil crops of National Academy of Agrarian Science (Zaporizhia, Ukraine). Rape (Brassica napus) seeds of winter (Artus, Lembke KG, Germany) variety were collected from local oil market. The chemical composition of soy beans: $11.3 \%$ moisture, $39.2 \%$ (dry basis) protein, $29.8 \%$ (dry basis) lipids, and 5.9\% (dry basis) ash. Sunflower KP11B is a linoleic variety ( $62.5 \%$ of total content of fatty acids). The sunflower seeds contained $6.7 \%$ moisture, $48.2 \%$ (dry basis) lipids, $16.7 \%$ (dry basis) proteins, and 7.3\% (dry basis) ash. The rape seeds contained $4.2 \%$ moisture, $43.6 \%$ (dry basis) lipids, $23.7 \%$ (dry basis) proteins, $5.6 \%$ (dry basis) ash, and $0.8 \%$ (dry basis) glucosinolates.

\section{Proximate analyses}

Moisture content of seeds was determined using the gravimetric method. Fat content of seeds was measured according to Soxhlet's method. For this purpose $2 \mathrm{~g}$ of sample were extracted for $24 \mathrm{hrs}$ using hexane as a solvent. Crude protein (Nx6.25) was determined by the Kjeldahl method according to AOAC Method [27]. Content of total soluble proteins in seeds were determined suspending $5 \mathrm{~g}$ of defatted meal in water solution at $\mathrm{pH} 10$, adjusted with $1 \mathrm{~N} \mathrm{NaOH}$. Suspensions were mixed by agitation during $90 \mathrm{~min}$. Suspensions were centrifuged for $15 \mathrm{~min}$ at $3,500 \mathrm{rpm} / \mathrm{min}$. Concentration of soluble proteins in supernatants were determined by Biuret method [28] using bovine serum albumin as standard.

Ash content was determined by igniting the samples at $550{ }^{\circ} \mathrm{C}$ in a muffle furnace until light grey ash resulted. Glucosinolate content was measured as glucose released from glucosinolates in stoichiometric amounts under hydrolysis by the endogenous enzyme myrosinase using GLUCOTEST paper according to Interstate Standard [29]. For glucosinolate hydrolysis $0.5 \mathrm{~g}$ of crushed seeds were mixed with $5 \mathrm{~mL}$ of distilled water and incubated in the presence of activated carbon during $2 \mathrm{~min}$. 


\section{Determination of toxicity and relative nutritive value of protein products}

Tetrachimena piriformis (WH-14 strain) cultures were used for the determination of relative nutritive value and toxicity of the protein products. The dead cells, changed shapes, characteristic of movement and growth depression of infusoria were measure of toxicity. 50 $\mathrm{mg}$ of protein samples, $2 \mathrm{~mL}$ of sea salt solution $(5.6 \mathrm{mg} / \mathrm{mL}, \mathrm{pH} 7.0)$ and $0.04 \mathrm{~mL}$ of 3days Tetrachimena piriformis cultures were placed in vials, mixed and incubated in thermostat at $25^{\circ} \mathrm{C}$ during 24 and $72 \mathrm{~h}$. For better aeration the vials were periodically shake during incubation. After incubation infusoria cells were fixed in iodine solution in ethanol $(50 \mathrm{~g} / \mathrm{kg})$ and analyzed under light microscope. Cell quantity was determined using counting chamber. The control samples contained casein instead of seed protein products. Relative nutritive values of investigated samples were represented as a number of cells grown per sample, compared with the control.

\section{Protein isolation}

Proteins were extracted from defatted seeds by sodium chloride solution $(70 \mathrm{~g} / \mathrm{L}, \mathrm{pH}$ 7.0) under constant stirring and temperature $50-55^{\circ} \mathrm{C}$ during $40-50 \mathrm{~min}$, meal: solution ratio was 1:10 (w:v). After this insoluble residues were precipitated by centrifugation $(1000 \mathrm{~g}, 15 \mathrm{~min})$. The supernatant (protein extract) was used for isoelectric protein precipitation at $\mathrm{pH}$ 4.5. After protein coagulation pellet was separated from whey by centrifugation $(3000 \mathrm{~g}, 15 \mathrm{~min})$, washed with distilled water at $\mathrm{pH} 4.5$, collected and dried at $55-60{ }^{\circ} \mathrm{C}$ to $6-8 \%$ moisture.

\section{Determination of amino acid composition of protein isolates}

The direct acid hydrolysis of protein isolates was used to obtain hydrolysates suitable for determination of all amino acid except cysteine and tryptophan. Hydrolysis was carried out in test tubes by adding of $1 \mathrm{~mL} \mathrm{HCl}$ to dry sample, corresponding to $2 \mathrm{mg}$ of protein. The mixture was frozen in a bath at $-80^{\circ} \mathrm{C}$, evacuated, sealed and then samples were exposed at $106^{\circ} \mathrm{C}$ for $24 \mathrm{~h}$ in a thermostat. After hydrolysis samples were cooled and $\mathrm{HCl}$ was removed from them by evacuating in dessicator containing $\mathrm{NaOH}$ pellet. After drying of samples $4 \mathrm{~mL}$ of deionized water was added and drying procedure was repeated. Dry samples were dissolved in citrate buffers $(0.3 \mathrm{M} / \mathrm{L}, \mathrm{pH} 2.2)$ and used for amino acid analyses.

Amino acid analyzer T 339 (Czech Republic) was used for amino acid content analysis. Standard amino acid mixture containing $0.5 \mu \mathrm{M}$ of the 17 commonly occurring amino acid was used to calculate the amount of amino acids in the samples.

\section{Determination of proteins functional properties}

Determination of protein products solubility were performed according to [30] using solutions with $\mathrm{pH}$ values from 2 to 10 , adjusted with $1 \mathrm{~N} \mathrm{HCl}$ or $1 \mathrm{~N} \mathrm{NaOH}$, and protein concentration $1 \mathrm{mg} / 1 \mathrm{ml}$. Prepared protein suspensions were mixed by shaker during $1 \mathrm{~h}$. Suspensions were centrifuged for $30 \mathrm{~min}$ at $3,500 \mathrm{~g}$. Concentration of soluble proteins were determined in the supernatant by Biuret method [28] using bovine serum albumin as standard.

The water holding capacities (WHC) of the extracted seed proteins were measured as described by Ashraf et al. [31] taking $1 \mathrm{~g}$ of protein extract and resuspended in $10 \mathrm{~mL}$ of 
distilled water and mixed vigorously for 2 minutes, the supernatants obtained after centrifugation at $3000 \mathrm{x}$ g for $20 \mathrm{~min}$, were decanted and the weights of the sediments were determined, the WHC values expressed as gram of water absorbed per $100 \mathrm{~g}$ of protein extracted.

The oil binding capacities (OBCs) of the extracted seed proteins were measured using the method of Ashraf et al. [31] taking $1 \mathrm{~g}$ of protein, deposited and reweighed in $50 \mathrm{~mL}$ centrifuge tubes and thoroughly mixed for $3 \mathrm{~min}$ with $10 \mathrm{~mL}$ of vegetable oil. Samples were allowed to stand for $30 \mathrm{~min}$ and the mixtures were centrifuged at $3000 \mathrm{xg}$ for $20 \mathrm{~min}$, the supernatants were carefully poured immediately after the centrifugation and tubes with the sediments were weighted. The $\mathrm{OBC}$ values expressed as gram of oil absorbed per $100 \mathrm{~g}$ of protein isolates.

The emulsifying capacity (EC) of the extracted seed proteins were determined according to Karki et al. [32] taking $8.5 \mathrm{~g}$ of each sample and mixed with $50 \mathrm{~mL}$ of distilled water for 2 min using a blender and vegetable oil was adding slowly with continuous blending. The process was stopped after every 2 min to check for emulsion breakage. The maximum volumes of oil that was emulsified were measured and emulsifying capacity was determined as volume of oil relatively to $1 \mathrm{~g}$ of protein isolates.

The foaming capacity (FC, \%) of the extracted seed proteins was determined according to Makri et al. [33] taking $1 \%$ of the protein extracted and resuspended in deionized water, $\mathrm{pH}$ was adjusted to 7.4 with $0.1 \mathrm{~N} \mathrm{NaOH}$ and $0.1 \mathrm{~N} \mathrm{HCl} .100 \mathrm{~mL}$ of solution were blended for 3 minutes and poured into a $500 \mathrm{~mL}$ graduated cylinder. The volume of foam $\left(\mathrm{V}_{\mathrm{f}}\right)$ and liquid $\left(\mathrm{V}_{1}\right)$ were immediately recorded and $\mathrm{FC}$ was calculated using the following equation:

$$
\mathrm{FC}=\frac{V_{f}}{V_{l}} \cdot 100
$$

Foam stabilities of proteins suspensions (\%) were determined as ratio of undestroyed foam volume after $5 \mathrm{~min}$ to initial volume of foam.

\section{Statistical analysis}

Samples were analyzed by triplicate. Statistical analysis was performed using Microsoft Excel 2007 (Microsoft, City of Redmond, USA). The results were reported as mean \pm SD. Differences were considered to be significant at validity $\alpha=0.95$.

\section{Results and discussion}

\section{Biological value and safety of oil seed protein products}

Measuring of oil seed protein products toxicity was carried out using Tetrachimena piriformis (WH-14 strain) cultures and neither dead cells, nor changed shapes of cells or their movement, nor growth depression of infusoria were detected. Infusoria cells had usual shape, were active, fissionable in the presence of every studied meal - soy, sunflower and low glucosinolate rape.

Relative nutritive values of defatted oil seeds and isolated proteins were calculated on the basis of nutritive value of casein (control). Defatted oil seeds meal had high nutritive value, varying from $92 \%$ (for rape meal) to $98 \%$ (for soybean meal) comparing with casein (Figure 1). Slight decrease of rape meal value probably was caused slight glucosinolates content. In spite of this isolated rape proteins had even higher nutritive value than rape seed 


\section{- Food Technology —}

meal that evidently caused by reduction of glucosinolates content. Indeed, isolated proteins contained about half of glucosinolates meal content. At the same time insoluble residue of rape meal had the highest glucosinolates content (Figure 2).

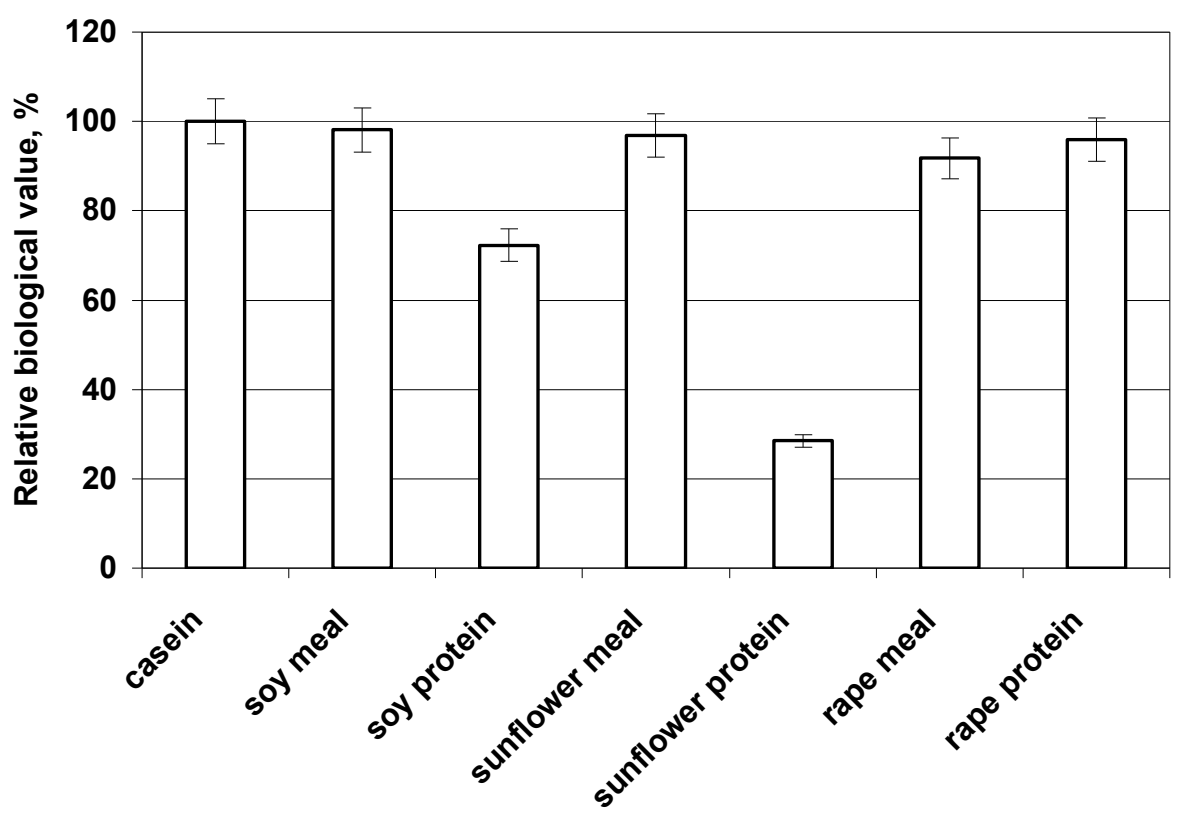

Figure 1. Relative nutritive values of protein products.

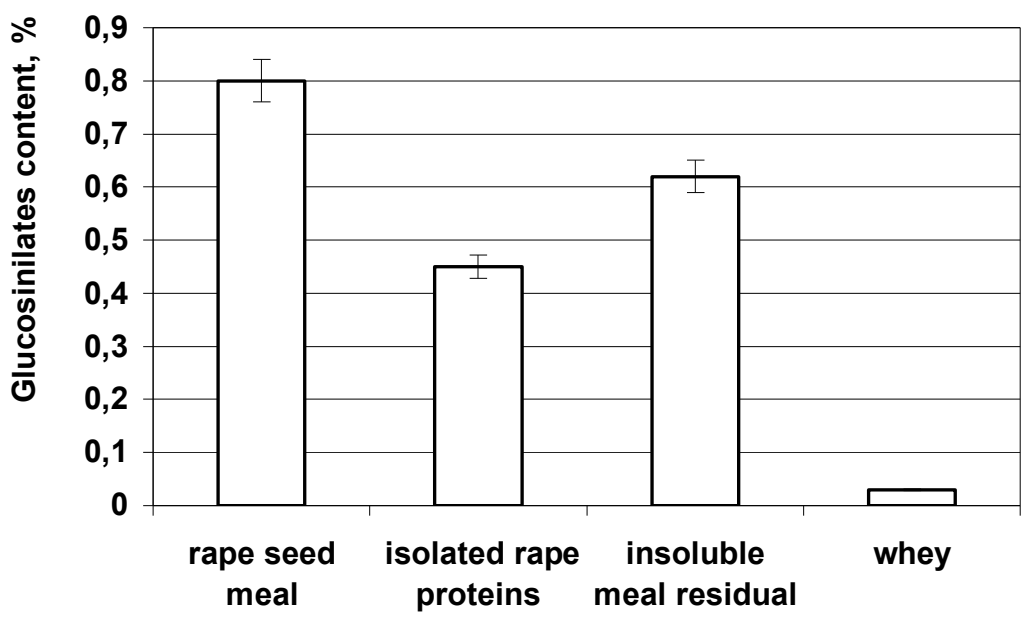

Figure 2. Glucosinolates content in rape seeds and their derivatives (glucosinolates content is given on the dry basis) 
The relative biological value of isolated soy proteins had decreased to $72.3 \%$ that was about $74 \%$ of soy meal value. The value of sunflower isolated proteins had decreased most drastically and was only $28.5 \%$ comparing with casein. Such decline of nutritive values probably was resulted by loosing of high biological value proteins which retaining in whey water. As it is known, this fraction of proteins is albumins, which are not precipitated at $\mathrm{pH}$ 3.8-4.5, corresponding isoelectric point of globulins [34]. Content of albumin fractions were 5.7, 6.8 and $36.2 \%$ in soybeans, sunflower and rape seeds respectively. Rape seeds albumin fraction is most abundant, but it was shown in early works the biological value of rape albumin napin had been limited by content of tyrosine, which is only $23 \%$ of FAO/WHO scale protein [35].

The main characteristic of proteins biological value is content of indispensable amino acids and their score to FAO/WHO scale protein. The protein isolate from rape seeds had highest biological value (Table 1), valine and isoleucine were limited amino acids with their score to scale protein 80 and $85 \%$, respectively. Scores of other essential amino acids were higher than $100 \%$.

Content of sulfur containing amino acids methionine and cystine had limited value of soy seeds protein isolates, their score was only $60 \%$, the threonine score was about $100 \%$ and content of other essential amino acids was higher their content in scale protein.

The sunflower seeds protein isolates were of lowest quality. Their value was limited by the content of sulfur containing amino acids, which was less than $50 \%$ of scale protein. The lysine was the second limiting amino acid, its score was only a negligible higher of methionine and cystine score. Content of other amino acids exceeded that of scale protein.

It is known that biological value of protein isolates depend from number of factors such as genetic properties of plants, climate conditions of seeds growing, and most of all from the parameters of seeds processing. The chemical composition and quality of proteins can be changed significantly as result of seeds processing (drying, heating, pressing, extraction and desolvation of meal) and protein recovery from meal, their precipitation from solution and drying. Therefore the published data about indispensable amino acids content of seed proteins and protein isolates are not identical. Usually content of all essential amino acids in soy protein isolates are higher [37].

Table 1

Content of main indispensable amino acids in soy and rape protein isolates relative to FAO/WHO scale protein.

\begin{tabular}{|c|c|c|c|c|c|c|c|}
\hline \multirow[t]{2}{*}{ Amino acid } & \multirow{2}{*}{$\begin{array}{c}\text { FAO/WHO } \\
\text { protein, } \\
\text { mg/100mg } \\
\text { of protein } \\
{[36]}\end{array}$} & \multicolumn{2}{|c|}{$\begin{array}{c}\text { Soybean protein } \\
\text { isolate }\end{array}$} & \multicolumn{2}{|c|}{$\begin{array}{l}\text { Sunflower seeds } \\
\text { protein isolate }\end{array}$} & \multicolumn{2}{|c|}{$\begin{array}{c}\text { Rape protein } \\
\text { isolate }\end{array}$} \\
\hline & & $\begin{array}{c}\mathrm{mg} / \mathbf{1 0 0} \\
\mathrm{mg} \text { of } \\
\text { protein }\end{array}$ & $\begin{array}{c}\% \text { to } \\
\text { FAO/WHO } \\
\text { protein }\end{array}$ & $\begin{array}{c}\mathrm{mg} / 100 \\
\mathrm{mg} \text { of } \\
\text { protein }\end{array}$ & $\begin{array}{c}\% \text { to } \\
\text { FAO/WHO } \\
\text { protein }\end{array}$ & $\begin{array}{c}\mathrm{mg} / 100 \\
\mathrm{mg} \text { of } \\
\text { protein }\end{array}$ & $\begin{array}{c}\% \text { to } \\
\text { FAO/WHO } \\
\text { protein }\end{array}$ \\
\hline Lysine & 5.5 & $6.1 \pm 0.18$ & 110.9 & $3.0 \pm 0.17$ & 54.2 & $6.5 \pm 0.20$ & 118.2 \\
\hline $\begin{array}{c}\text { Methionine+ } \\
\text { Cystine }\end{array}$ & 3.5 & $2.1 \pm 0.06$ & 60.0 & $1.6 \pm 0.16$ & 45.7 & $5.5 \pm 0.17$ & 157.1 \\
\hline Valine & 5.0 & $5.4 \pm 0.16$ & 108.0 & $6.2 \pm 0.11$ & 123.8 & $4.0 \pm 0.12$ & 80.0 \\
\hline Threonine & 4.0 & $3.9 \pm 0.12$ & 97.5 & $4.4 \pm 0.14$ & 109.3 & $4.3 \pm 0.13$ & 107.5 \\
\hline Leucine & 7.0 & $7.9 \pm 0.24$ & 112.9 & $7.8 \pm 0.22$ & 110.9 & $7.0 \pm 0.21$ & 100.0 \\
\hline Isoleucine & 4.0 & $4.1 \pm 0.12$ & 102.5 & $5.5 \pm 0.10$ & 138.5 & $3.4 \pm 0.10$ & 85.0 \\
\hline $\begin{array}{c}\text { Pheyilalanine } \\
+ \text { Tyrosine }\end{array}$ & 6.0 & $8.0 \pm 0.23$ & 133.3 & $8.6 \pm 0.23$ & 143.5 & $7.5 \pm 0.23$ & 125.0 \\
\hline
\end{tabular}




\section{- Food Technology -}

\section{Technological properties of oil seeds proteins}

Technological properties of proteins determine their using in food processing, influencing the rheological properties, emulsion or foam stability, plasticity, appearance and taste of food. The main technological properties are water solubility, capacities to stabilize emulsion and foam, water and oil binding capacities etc.

The water soluble protein fraction content in soy, sunflower and rape seeds were mention above. Content of total soluble proteins were $85.2,84.3$ and $70.8 \%$ of protein content in rape, soy and sunflower seeds respectively. Mass of total soluble proteins, which were determined in alkaline medium, was lowest in sunflower seeds. Apart from genetic peculiarities of protein fraction composition, using of alkaline medium under protein extraction from defatted sunflower seeds had resulted changing of isolated proteins color and water solubility due to creation of complexes between proteins and products of chlorogenic acid oxidation [38]. Colors of these isolated proteins were from bright green to dark green. On the contrary, it was shown that protein recovery in salt solution maintained their native state [39].

After protein recovery in neutral solution (sodium chloride), isoelectric precipitation and protein drying, water solubility of isolated proteins was not as high at every $\mathrm{pH}$, the maximal solubility was determined to be only about $38 \%$ for rape proteins (Figure 3 ).

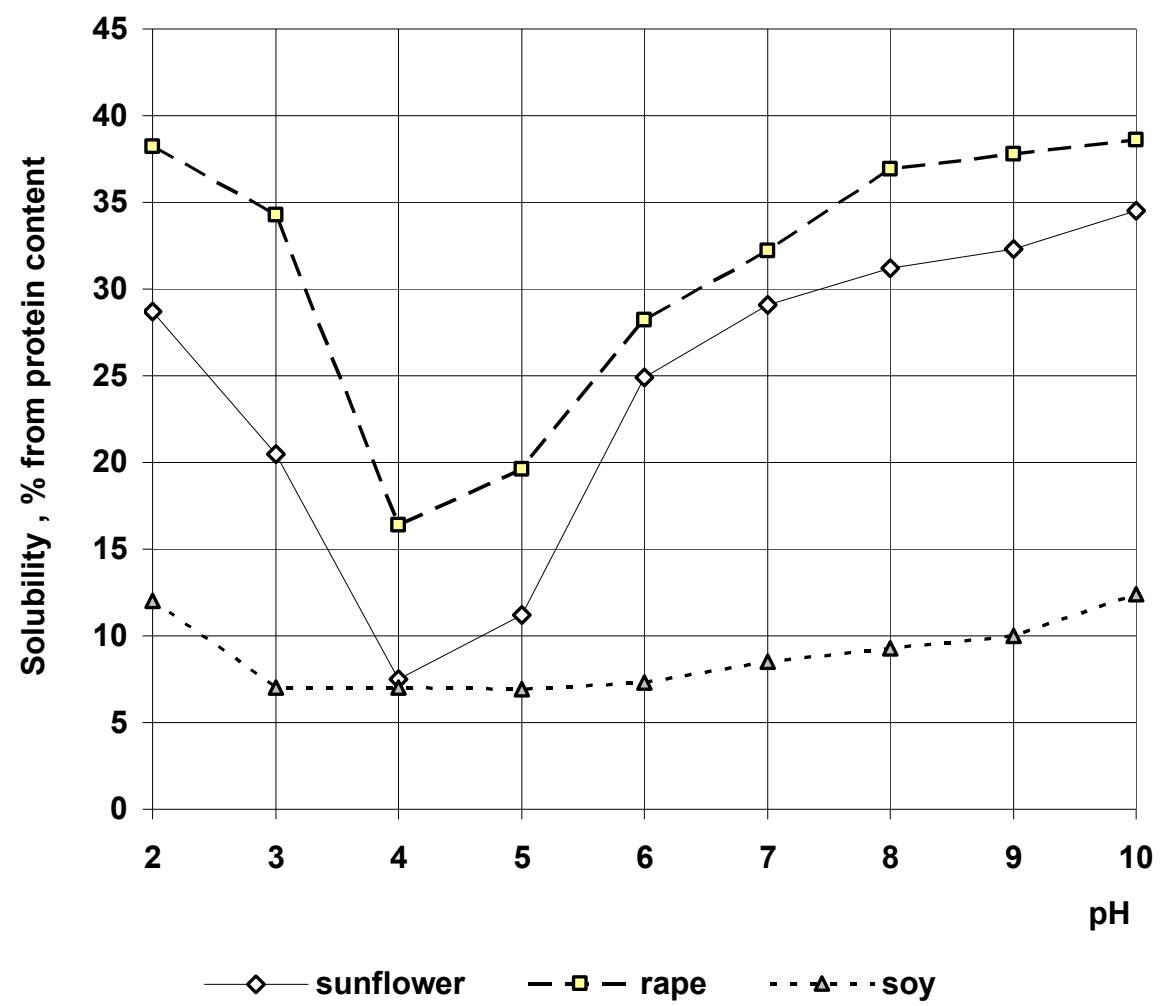

Figure 3. Solubility of protein isolates from oil seeds at different $\mathrm{pH}$ values 
Evedently, that this is the result of solubility changes of primary soluble seed proteins under isolation procedure. Lowest protein solubility was at $\mathrm{pH} 4-5$ and highest - in alkaline medium. Additional water washing of isoelectric precipitated protein pellets had increased protein solubility by $10-15 \%$ at $\mathrm{pH} 7-8$ (data not shown). Rape proteins isolate had higher solubility relatively soy and sunflower isolates at all $\mathrm{pH}$ range. High rape proteins isolate solubility in water solutions probably caused by high albumin content in rape seeds. It is known, that rape proteins solubility is determined by their isolation procedure. Protein isolates, prepared by isoelectric precipitation, consist of $7 \mathrm{~S}$ globulins and have a poor solubility [40], but a good solubility of isolates, precipitated with acid were reported too [41].

Solubility of isolated sunflower proteins had dropped drastically at $\mathrm{pH}$ range 4-5 and was highest (about $35 \%$ ) at $\mathrm{pH} 10$. At the same time it was shown that protein isolates, prepared from sunflower oil cake, had very high solubility (above $80 \%$ at $\mathrm{pH} 8$ ) [30]. For this purpose authors had suspended isoelectric protein pellet in water at $\mathrm{pH} 9$ and suspension was dried lyophilization.

Isolated soy proteins had very low solubility in studied $\mathrm{pH}$ range. It could be resulted by presence of polypeptides with higher molecular weight in soy protein isolates, which abounded by polypeptides with molecular weight from 30 to $76 \mathrm{kDa}$ [42], whereas sunflower protein isolates - by polypeptides with molecular weight from 20 to $45 \mathrm{kDa}[34$, $43,44]$ and rape protein isolates - by polypeptides with molecular weight $12-50 \mathrm{kDa}$ [45]. Similar values of soy proteins isolate solubility were obtained by Molina Ortiz and Cristina An [46].

As the result of high molecular weight of soy protein isolates their water holding capacity was very high (385\%), that was the highest value compare with sunflower and rape protein isolates (Figure 4, a). The sunflower protein isolate had lowest degree of hydrophility, it was about $160 \%$. The highest oil binding capacity was detected for rape proteins isolate (Figure 4, a). Probably this is due to high content of hydrophobic sulfur containing amino acids in rape proteins. The sunflower and soy protein isolates still had high capacity to oil absorption.

The rape protein isolate had also highest foam and emulsifying capacities comparing with sunflower and soy protein isolates (Figure $4, b$ ), though most rape protein isolates were reported to have poor foaming capacity $[47,48]$. At the same time foam of rape protein suspension was unstable. It is known, that foam and emulsifying capacities are depended from hydrophobicity of proteins. Thus isolated rape proteins having relative high water solubility had demonstrated higher hydrophobic properties too. In spite of this the opposite data about relationship between rape protein isolates solubility and their emulsifying capacity were reported [40].

Salgado et al. [30] had proposed that protein aggregation had resulted in decrease of surface hydrophobicity. On the contrary, it is possible, that high solubility and surface hydrophobicity of isolated rape proteins were associated with their disaggregation. 


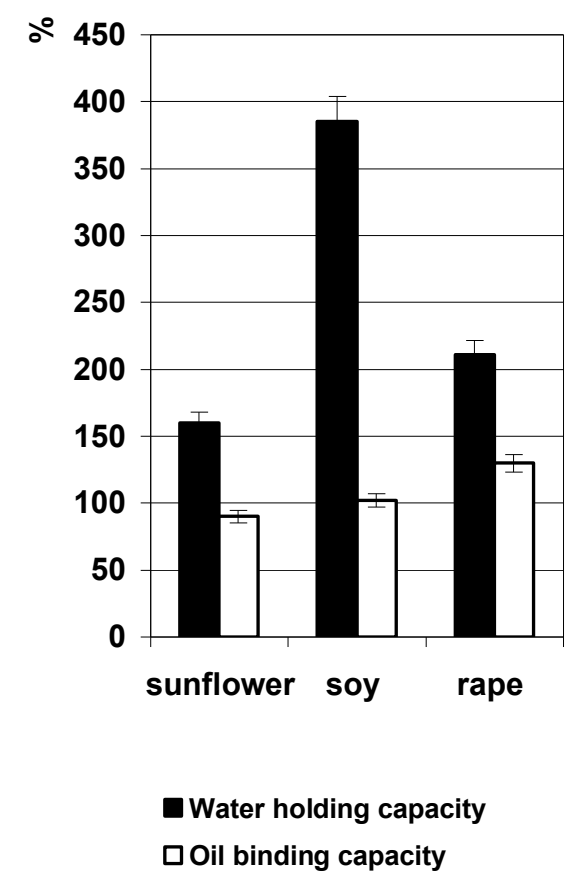

$a$

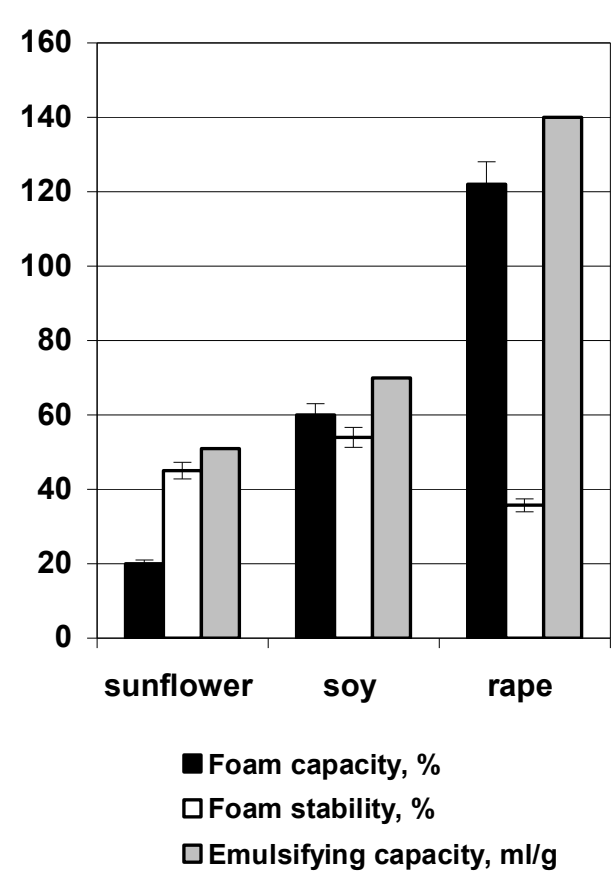

b

Figure 4. Technological properties of protein isolates from oil seeds

\section{Conclusion}

Investigated protein isolates of oil seeds (soy, sunflower and rape) had no toxicity according to test with Tetrachimena piriformis. Rape proteins isolate had the highest relative biological values comparing with soy and sunflower isolated proteins. Relative biological value of sunflower isolated proteins was poor. Rape protein isolate had also the highest value on the basis of indispensable amino acids content. This value was districted only by valine score $(80 \%$ of scale $\mathrm{FAO} / \mathrm{WHO}$ protein) and isoleucine $(85 \%$ of scale protein). Soy and sunflower isolated proteins were diminished by sulfur containing amino acids. The water solubility, oil binding, foam and emulsifying capacities of rape proteins isolate were also higher comparing with soy and sunflower isolated proteins.

Thus isolated proteins of low glucosinolate rape seeds are promising source of edible proteins, which have enhanced technological properties. The technological properties of soy and sunflower isolated proteins can be modified by limited enzymatic hydrolyses or other treatment.

\section{Acknowledgements}

Authors are thankful to Dr. V. Dzhmil (Department of veterinary and sanitary expertise of Agrarian University) for his valuable support of researchings of toxicity and nutritive value of rape products. 


\section{References}

1. Murphy P. Soybean proteins, In: Johnson L., White P., Galloway R. (2009), Soybeans: chemistry, production, processing, and utilization, AOCS Press, Urbana, pp. 229-269.

2. Aoki H., Taneyama O., Inami M. (1980), Emulsifying Properties of Soy Protein: Characteristics of $7 \mathrm{~S}$ and $11 \mathrm{~S}$ Proteins, J. Food Sci, 45(3), pp. 534-538.

3. Kangll J., Matsumura Y., Mori T. (1991), Characterization of texture and mechanical properties of heat-induced soy protein gels, J Am Oil Chem Soc, 68(5), pp. 339-345.

4. Utsumi S., Matsumura Y., Mori T. Structure-function relationships of soy proteins, In: Damodaran, S., Paraf, A. (1997), Food proteins and their applications, Marcel Dekker Inc, New York; pp. 257-291.

5. Teng Z., Liu C., Yang X. et al. (2009), Fractionation of Soybean Globulins Using $\mathrm{Ca}^{2+}$ and $\mathrm{Mg}^{2+}$ : A Comparative Analysis, J Am Oil Chem Soc, 86(5), pp. 409-417.

6. Berk, Z. (1992), Technology of production of edible flours and protein products from soybeans, Food and Agriculture Organization of the United Nations: FAO Agricultural services Bulletin, 97.

7. Nazareth Z. M., Deak N. A., Johnson L. A. (2009), Functional Properties of Soy Protein Isolates Prepared from Gas-Supported Screw-Pressed Soybean Meal, J Am Oil Chem Soc, 86(4), pp. 315-321.

8. Bainy E. M., Tosh S. M., Corredig M. et al. (2008), Protein Subunit Composition Effects on the Thermal Denaturation at Different Stages During the Soy Protein Isolate Processing and Gelation Profiles of Soy Protein Isolates, $J$ Am Oil Chem Soc, 85(6), pp. 581-590.

9. Fukushima D. (1969), Denaturation of Soybean Proteins by Organic Solvents, Cereal Chem., 46(2), pp. 156-163.

10. Lhocine L., Boye J. I., Arcand Y. (2006), Composition and Functional Properties of Soy Protein Isolates Prepared Using Alternative Defatting and Extraction Procedures, J. Food Science, 71(3), pp. 137-145.

11. González-Pérez S., Vereijken J. M., Merck K. B. et al. (2004), Conformational states of sunflower (Heliantus annuus) Heliantinin: effect of heat and pH, J. Agric. Food Chem., 52(22), pp. 6770-6778.

12. Molina M. I., Petruccelli S., Anon M. C. (2004 ), Effect of pH and Ionic Strength Modifications on Thermal Denaturation of the 11S Globulin of Sunflower (Helianthus annuus), J. Agric. Food Chem., 52(19), pp. 6023-6029.

13. Gonzalez-Perez S., Vereijken J. M. (2007), Sunflower proteins: overview of their physicochemical, structural and functional properties, J. Sci. Food Agric., 87(12), pp. 2173-2191.

14. Ivanova P., Chalova V., Koleva L. et al. (2013), pp. Amino acid composition and solubility of proteins isolated from sunflower meal produced in Bulgaria. Int. Food Res. J. 20(6), pp. 2995-3000.

15. Hoglund A. S., Rodin J., Larsson E. et al. (1992), Distribution of napin and cruciferin in developing rape seed embryos, Plant Physiol., 98(2), pp. 509-515.

16. Wanasundara J. P. D. (2011), Proteins of Brassicaceae Oilseeds and their Potential as a Plant Protein Source, Critical Reviews in Food Science and Nutritio, 51(7), pp. 635677.

17. Rubin L. J., Diosady L. L., Phillips C. R. (1984), Patent №4 460504 United States. Solvent extraction of oilbearing seeds. 
18. Rubin L. J., Diosady L. L., Naczk M. et al. (1986), pp. The alkanol-ammonia-waterhexane treatment of canola, Can. Inst. Food Sci. technol. J., 19(2), pp. 547-561.

19. Diosady L. L., Rubin L. J., Phillips C. R. et al. (1985), pp. Effect of alkanolammonia-water treatment on the glucosinolate content of rapeseed meal, Can. Inst. Food Sci., Technol. J., 18(4), pp. 311.

20. Diosady, L. L., Tzeng, Y. M., Rubin, L. J. (1984), Preparation of rapeseed protein concentrates and isolates using ultrafiltration, J. Food Sci., 49(3), pp. 768-770.

21. Tzeng Y. M., Diosady L. L., Rubin L. J. (1988), Preparation of a rapeseed protein isolate using sodium hexametaphosphate extraction, ultrafiltration, diafiltration and ion-exchange, J. Food Sci., 53(5), pp. 1537-1541.

22. Tzeng Y. M., Diosady L. L., Rubin L. J. (1988 ), Preparation of rapeseed protein isolates using ultrafiltration, precipitation and diafiltration, Can. Inst. Food Sci. technol. J., 21(3), pp. 419-423.

23. Tzeng Y. M., Diosady L. L., Rubin L. J. (1990), Production of canola protien materials by alkaline extraction, precipitation and membrane processing, J. Food Sci., 55(4), 1147-1151.

24. Diosady L. L. et al. (2005), Patent №6 905713 B2, United States. Production of high quality isolates from defatted meals of Brassica seeds.

25. Gu X., Dong, W., He Y. (2011), Detoxification of Rapeseed Meals by Steam Explosion, J Am Oil Chem Soc, 88(11), pp. 1831-1838.

26. Fahey J. W., Zalcmann A. M., Talalay P., Fahey J. W. (2001), The chemical diversity and distribution of glucosinolates and isothiocyanates among plants, Phytochemistry, 56(1), pp. 5-51.

27. (1984), Official Methods of Analysis, 14th edn., Assotiation of Official Analytical Chemists, Washington.

28. Wrosltad R. E., Acree T. E., Decker E. A. et al. (2004), Handbook of food analytical chemistry, John Wiley \& Sons, New Jersey.

29. (1987), Interstate Standard GOST 9824-87. Rape and colza seeds. Varietal and sowing characteristics. Specification, Standard publisher, Moscow.

30. Salgado P. R., Molina Ortiz S. E., Petruccelli S. et al. (2011), Sunflower Protein Concentrates and Isolates Prepared from Oil Cakes Have High Water Solubility and Antioxidant Capacity, J Am Oil Chem Soc, 88(3), pp. 351-360.

31. Ashraf S., Saeed S. M. G., Sayeed S. A., Ali, R. (2012), Impact of microwave treatment on the functionality of cereals and legumes, Int. J. Agric. Biol., 14, pp. 365370.

32. Karki B., Lamsal B. P., Grewell D. et al. (2009), Functional properties of soy protein isolates produced from ultrasonicated defatted soy flakes, $J$ Am Oil Chem Soc, 86(10), pp. 1021-1028.

33. Makri E., Papalamprou E., Doxastakis G. (2005), Study of functional properties of seed storage proteins from indigenous European legume crops (lupin, pea \& broad bean) in admixture with polysaccharides, Food Hydrocolloids, 19(3), pp. 583-594.

34. Pickardt C., Hager T., Eisner P. et al. (2011), Isoelectric protein precipitation from mild-acidic extracts of de-oiled sunflower (Helianthus annuus L.) press cake, Eur. Food Res. Technol., 233(1), pp. 31-44.

35. Schwenke K. D., Raab B., Linow K. J. et al. (1981), Isolation of the 12 S globulin from Rapeseed (Brassica napus L.) and characterization as a "neutral" seed proteins. Part 13. Food Nahrung, 25(3), pp. 271-280. 


\section{- Food Technology -}

36. Energy and protein requirements. (1973), Reports of a joint FAO/WHO Ad hoc expert committee. World Health Organization Technical Report Series. № 522. WHO. Geneva, Switzerland.

37. Endres J. G. (2001 ), Soy Protein Products Characteristics, Nutritional Aspects, and Utilization. AOCS Press, Champaign, Illinois, $61 \mathrm{p}$.

38. Shcherbacov V. G., Ivanickiy S. B. (1987), Production of protein products from oil seeds. Agropromizdat, Moscow. (in Russian).

39. Ismond M. A. H., Welsh W.D. (1992), Application of new methodology to canola protein isolation, Food Chemistry, 45(2), pp. 125-127.

40. Arntfield S. D. (2011), Canola and other oilseeds proteins, In: Phillips G. O. and Williams P. A. Handbook of food protein, Woodhead Publishing Limited; pp. 289315 .

41. Thompson L. U, Liu R. F. K, Jones J. D. (1982), Functional properties and food applications of rapeseed protein concentrate, J Food Sci, 47, pp. 1175-1180.

42. Medic J., Atkinson C., Hurburgh C. R. (2014 ), Current Knowledge in Soybean Composition, J Am Oil Chem Soc, 91(3), pp. 363-384.

43. Villanueva A., Vioque J., Sánchez-Vioque R. et al. (1999), Peptide characteristics of sunflower protein hydrolysates, J Am Oil Chem Soc, 76(12), pp. 1455-1460.

44. Nosenko T., Mank V., Zhukova Y., Cherstva A. (2016), Composition and Properties of Partially Hydrolyzed Sunflower Protein Isolates, Ukrainian Food Journal, 5(3), pp. 451-461.

45. Schwenke K. D., Dahme A., Wolter Th. (1998), Heat-indunced gelation of rapeseed proteins: Effect of protein interaction and acetylation, J Am Oil Chem Soc, 75(1), pp. 83-87.

46. Molina Ortiz S. E, Cristina An. M. (2000), Analysis of products, mechanisms of reaction, and some functional properties of soy protein hydrolysates, $\mathrm{J} \mathrm{Am} \mathrm{Oil}$ Chem Soc, 77(12), pp. 1293-1301.

47. Malabat C., Sanchez-Vioque R., Rabiller C. et al. (2001), Emulsifying and foaming properties of native and chemically modified peptides from the $2 \mathrm{~S}$ and $12 \mathrm{~S}$ proteins of rapeseed (Brassica napus L. ), J Am Oil Chem Soc, 78(3), pp. 235-241.

48. Vioque J., Sánchez-Vioque R., Clemente A. et al. (2000), Partially hydrolyzed rapeseed protein isolates with improved functional properties, $J$ Amer Oil Chem Soc, 77(4), pp. 447-450. 